\title{
EFFECT OF SOIL AMENDMENT WITH SEWAGE SLUDGE ON WHEAT GROWTH AND PRODUCTIVITY
}

\author{
Mohamed A. I. Mansour ${ }^{1}$, Abdul-Wahid F. Moustafa ${ }^{2}$ \\ and Ahmed El-Badawy M. Shokr ${ }^{1}$ \\ 1. Department of Botany, Faculty of Sciences, Suez Canal University, Al-Arish 45511, Egypt. \\ 2. Department of Botany, Faculty of Sciences, Suez Canal University, Ismailia 41522, Egypt.
}

\begin{abstract}
Wheat as a cereal crop might display the top among all strategic crops, in Egypt the annual production is always behind the need and the gap between production and consumption remain great. The main target of the present investigation has been to study the effect of sewage sludge as organic fertilizer on wheat as a major cereal crop in Egypt. Composted and air-dried sewage sludge was obtained from the Municipal Wastewater Treatment Station at Al-Sheikh-Zowaied and applied at three rates for comparison, these rates were: $10 \%, 20 \%$ and $30 \%$. For experimentation, the recommended cultivar Sakha-93 of Triticum aestivum L. was obtained and field experiments were conducted within the University Agriculture Farm at AlArish where the soil is typically sandy loam with little silt and clay. From each treatment, three plant samples were collected during the vegetative and reproductive phases and finally at the grain stage for comparing growth, productivity and yield-quality. The results indicated that fresh \& dry weight of plant parts increased greatly by increasing the amount of sewage sludge. The effect was more prominent at the flowering stage. All concentrations of sludge amendment showed prominent increase in fresh \& dry weight. Sludge amendment increased greatly total lipids, total protein and heavy metals absorption; however, the amount of increase was much higher compared to control natural soil. Growth and yield of wheat were greatly increased by sewage sludge amendment. The best yield (1.69 Ton/ Feddan) was reported at the sludge concentration of $20 \%$.
\end{abstract}

Key Words: Wheat, Sewage Sludge, Organic Fertilizer, Composted, Total Protein and Heavy Metals, Growth, Productivity \& Yield-Quality.

\section{INTRODUCTION}

\section{Importance of wheat as a crop:}

Wheat (particularly Triticum aestivum L.) is the first important and strategic cereal crop for the majority of world's populations. It is the most important staple food of about two billion people (36\% of the world population).

Worldwide, wheat provides nearly $55 \%$ of the carbohydrates and $20 \%$ of the food calories consumed globally.

It exceeds in acreage and productivity every other grain crop including rice, maize, etc. and is cultivated over a wide range of climatic conditions (Breiman \& Graur, 1995). It is planted annually in about 7.2 million ha ${ }^{-1}$ with an average annual yield of $1596 \mathrm{kgha}^{-1}$ and (Rangaraj et al., 2007).

\section{Challenges and problems related to wheat productivity worldwide:}

Challenges and problems are variable and numerous nevertheless, their types and intensity vary greatly from country to another but the major challenge could be the cultivar selection or preparation. For obtaining an appropriate cultivar of 
outstanding high productivity-potential and better disease-resistance, breading or genetic engineering has to be used as a matter of choice. Other challenges are very often starting in the field, continuing through harvesting, and extending during storage.

\section{Sewage sludge as a fertilizer usage and importance:}

Chemical fertilizers are usually used but most commonly leading to an increase of crop cost. To reduce such expenditure and to manage soil quality application of manure and sludge (as organic fertilizers) became an alternative source of plant nutrients.

The use of organic wastes on farms for agricultural purposes has been identified as a standard of good agricultural practices. These wastes constitute considerable resources of fertilizer components and organic matter, which is connected with their biological origin (Kalembasaet al., 2004; MosqueraLosadaet al., 2010).

Organic amendments to the soil are variable, may be in the form of chicken litter, oil cakes, rice husks, organic mulches, sludge or in the form of compost, farm-yard-manure, stablemanure, and green-manure.

\section{Sewage sludge can:}

1-modify soil physical, chemical and biological properties (Alcantara et al., 2009; Angın \& Yağanoğlu, 2009).

2-improve crop-yield by reducing the cost effect for nitrogen and phosphorus (Petersen et al., 2003).

3-increase plant growth rate, crop-yield and biomass (Samaras et al., 2008; Togay et al., 2008; Angın \& Yaganoğlu, 2011).

4- afford macronutrients like: N, P, K, Ca and $\mathrm{Mg}$, and micronutrients like: $\mathrm{B}, \mathrm{Cu}$,
$\mathrm{Fe}, \mathrm{Ni}$ and $\mathrm{Zn}$ (Yan et al., 2009; Du et al., 2012; Gu et al., 2013).

\section{MATERIALS AND METHODS:}

The main intention of the present investigation have been to compare between the effect of different sewage sludge concentrations (as an organic fertilizer) and control natural soil on the productivity of wheat as a major cereal crop in Egypt.

\section{Field design and experimentation:}

For field experiments, the recommended winter variety of wheat (Triticum aestivum L.), Sakha-93 was obtained from the Agricultural Research Center, Ministry of Agriculture, Giza. After being washed several times with tap water, wheat grains were surface sterilized by immersing in $1.5 \%$ sodium hypochlorite for three minutes followed by soaking in $70 \%$ ethanol for two minutes (Royse \& Ries, 1978) then rinsed with sterile water. For field cultivation, wheat grain amounts at the rate of $70 \mathrm{Kg} / \mathrm{Fed}$ were used.

Field experimentation has been conducted during early winter (November of the season 2012 and repeated in the next season November of 2013) in a plot within

The Agriculture Farm, Faculty of Agricultural \& Environmental Sciences at Al-Arish. The experimental plot was subdivided further into subplots $(2 \times 2 \mathrm{~m})$ where plants were grown in rows of 10 $\mathrm{cm}$ apart. In addition to natural soils control (C), three different concentrations of soil amended with sludge (S) at $10 \%$, $20 \%$ and $30 \%$.

This experiment was conducted under the natural conditions prevailing at the University Farm where the temperature showed a minimum of $14^{\circ} \mathrm{C}$ and a maximum of $17^{\circ} \mathrm{C}$ and the day-length was $14 \mathrm{~h}$ and the night-time was $10 \mathrm{~h}$ and the relative humidity of $60 \%$ and the lightintensity was $310 \mu \mathrm{Em}^{-2} \mathrm{~S}^{-1}$. Form each 
treatment, three groups of plant samples were collected randomly at different time intervals during the experiment of each season. The first two groups of samples at two different stages during the vegetative growth.

One group of samples at the tillering stage i.e after 55 days from sowing and another at the flowering stage i.e after 75 days from sowing.

After drying at $70^{\circ} \mathrm{C}$ for 7 days, dry fresh samples were ground into fine powder and tested for: a- heavy metals, btotal lipids and c- total protein.

The third group of samples (was represented by grains after maturity of kernels and yellowing of internodes i.e. after 150 days from sowing) was taken after harvesting to determine the following parameters: a- grain yield (Kg/fad), b- weight of 100 seeds, cconcentration of heavy metals, d-total lipids, e- total protein.

\section{Sludge characteristics}

Composted sludge was collected in polyethylene bags from the Municipal Wastewater Treatment Station at AlSheikh Zowaied, North-Sinai.

The obtained amount was air-dried and crushed and sieved through $2 \mathrm{~mm}$ sieve and kept in clean bags till use.

\section{Chemical properties:}

For the chemical characterization of sludge, $20 \mathrm{~g}$ samples were taken and subjected to chemical analysis of heavy metals content using the Standard Methods for the Examination of Water and Wastewater, 20 ${ }^{\text {th }}$ Edition (1999). Heavy metals concentrations were

determined after digestion in concentrated $\mathrm{H}_{2} \mathrm{SO}_{4}$ and $33 \% \mathrm{H}_{2} \mathrm{O}_{2}$ at $440^{\circ} \mathrm{C}$ (Digesdahl digestion apparatus of Hach).

The concentrations of metal ions were measured by atomic absorption spectro- scopy, using a Perkin Elmer Model 2380 Spectrophotometer Table (1).

Statistical analysis of the data obtained during this study was carried using statistical analysis of variance (ANOVA) according to Snedecor \& Cochran (1980) and the least significant difference (LSD) was calculated to determine the statistically significant treatment at 5\% level of significance for the error degree of freedom (Little \& Hills, 1978).

\section{RESULTS}

\section{Effect of sludge amendment on fresh and dry weight of wheat plants}

Three concentrations of sludge (S) namely $10 \%, 20 \%$, and $30 \%$ were studied in natural soil. Comparison was made at two different growth phases, at tillering (after 55 days) and flowering (after 75 days) and the results are given in Table (2).

The data clearly indicate that changes in the fresh and dry weight of shoots, roots and total plants follow almost a similar trend where weights clearly increased upon increasing the amount of sludge. By comparison, weights of all elements (shoots, roots and total plants) showed greater values at the flowering stage than at the tillering stage.

The results of Table (2), show also that by Comparison with control natural soil, sludge amendment significantly increased fresh \& dry weight of all elements. Comparing the effect of different sludge concentrations (S) at tillering and flowering stages and control natural soil, indicated that sludge amendment gave better values of growth parameters than control soil.

Amending sludge at the concentration of $30 \%$ to showed the most significant increase. 
Table (1): Heavy metal content of sludge.

\begin{tabular}{cc}
\hline Parameter & $\mathbf{m g} / \mathbf{l}$ \\
\hline Aluminum (AI) & 5.095 \\
Boron (B) & 1.356 \\
Cadmium (Cd) & 0.459 \\
Cobalt (Co) & 0.023 \\
Chromium (Cr) & 1.432 \\
Copper (Cu) & 48.630 \\
Iron (Fe) & 459.000 \\
Manganese (Mn) & 10.520 \\
Molybdenum (Mo) & 2.853 \\
Nickel (Ni) & 2.371 \\
Lead (Pb) & 36.465 \\
Strontium (Sr) & 6.225 \\
Vanadium (V) & 7.315 \\
Zinc (Zn) & 265.800
\end{tabular}

Table (2): Effect of different sludge concentrations on the fresh and dry weight of wheat plants at tillering and flowering stages.

\begin{tabular}{|c|c|c|c|c|c|c|c|}
\hline \multirow{2}{*}{$\begin{array}{c}\text { Growth } \\
\text { Stage }\end{array}$} & \multirow{2}{*}{ Treatment } & \multicolumn{3}{|c|}{ Fresh weight (gm) } & \multicolumn{3}{|c|}{ Dry weight (gm) } \\
\hline & & Shoot & Root & Total plant & Shoot & Root & Total plant \\
\hline \multirow{5}{*}{ 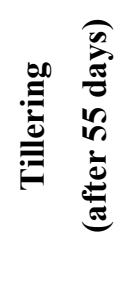 } & $\mathrm{C}$ & $0.98 \pm 0.13$ & $0.06 \pm 0.00$ & $1.05 \pm 0.13$ & $0.19 \pm 0.04$ & $0.02 \pm 0.02$ & $0.21 \pm 0.04$ \\
\hline & S $10 \%$ & $1.29 \pm 0.02$ & $0.15 \pm 0.03$ & $1.43 \pm 0.04$ & $0.20 \pm 0.01$ & $0.02 \pm 0.02$ & $0.22 \pm 0.08$ \\
\hline & S $20 \%$ & $1.31 \pm 0.02$ & $0.19 \pm 0.01$ & $1.50 \pm 0.02$ & $0.20 \pm 0.04$ & $0.03 \pm 0.04$ & $0.23 \pm 0.07$ \\
\hline & S $30 \%$ & $1.47 \pm 0.24$ & $0.22 \pm 0.03$ & $1.69 \pm 0.21$ & $0.25 \pm 0.04$ & $0.05 \pm 0.02$ & $0.30 \pm 0.06$ \\
\hline & LSD (5\%) & 0.51 & 0.06 & 0.50 & 0.20 & 0.07 & 0.21 \\
\hline \multirow{5}{*}{ 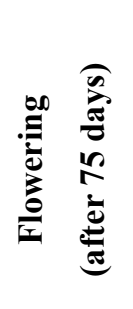 } & $\mathrm{C}$ & $7.14 \pm 0.13$ & $1.94 \pm 0.07$ & $9.06 \pm 0.14$ & $2.31 \pm 0.58$ & $1.35 \pm 0.31$ & $3.66 \pm 0.87$ \\
\hline & S $10 \%$ & $6.70 \pm 0.79$ & $2.81 \pm 0.09$ & $9.51 \pm 0.87$ & $2.34 \pm 0.15$ & $1.50 \pm 0.03$ & $3.84 \pm 0.14$ \\
\hline & S $20 \%$ & $7.57 \pm 0.54$ & $3.04 \pm 0.07$ & $10.61 \pm 0.61$ & $3.97 \pm 0.37$ & $1.62 \pm 0.08$ & $5.59 \pm 0.45$ \\
\hline & S $30 \%$ & $7.93 \pm 0.06$ & $3.59 \pm 0.04$ & $11.52 \pm 0.09$ & $4.49 \pm 0.31$ & $1.64 \pm 0.03$ & $6.13 \pm 0.28$ \\
\hline & $\operatorname{LSD}(5 \%)$ & 1.33 & 0.32 & 1.41 & 1.13 & 0.42 & 1.38 \\
\hline
\end{tabular}

Abbreviations: C; Control natural soil, S; Non- Mycorrhized soil treated with sludge, Values in the table are means \pm standard, LSD; least significant difference at $\mathrm{P}=0.05$. 
For example, the data of fresh shoots at the flowering stage, in sludge concentration of $30 \%$ showed an average weight of $11.52 \mathrm{gm}$ while $9.08 \mathrm{gm}$ in control soil.

\section{Effect of sludge amendment on total protein:}

Changes in total protein due to changes in the rate of sludge amendment (S) and are shown in Table (3), where the data clearly indicated that total protein, in plant tissues, follow the same trend by always being significantly high in sludgeamended soils by comparison with control.

At the flowering stage, the sludge amendment at concentration of $30 \%$ showed the highest amount of total protein $(9.73 \%)$. The same pattern of protein change in plant tissues upon changing sludge concentration (S) was also revealed by grains at the maturity stage.

\section{Effect of sludge amendment on heavy metals uptake:}

The effect of sludge (S) amendment (at different concentrations) and soil mycorrhization (M) separately and combined on the uptake of some heavy metals ( $\mathrm{Fe}, \mathrm{Cu}, \mathrm{Pb}, \mathrm{Zn}$ and $\mathrm{Mn}$ ) was studied at the flowering and grain maturity stages and the related data are given in Table (4).

The absorption of the five heavy metals under test, do not follow the same pattern. The data clearly indicated that upon increasing sludge alone (S), plants absorbed greater amounts of $\mathrm{Fe}, \mathrm{Cu}$ and $\mathrm{Pb}$ than mycorrhized soils, while $\mathrm{Zn} \&$ Mn showed the opposite trend by showing more absorption in mycorrhized than sludge-amended soils.

The combined treatment of mycorrhization and sludge amendment showed more a significant increase in $\mathrm{Zn} \& \mathrm{Mn}$ than $\mathrm{Fe}, \mathrm{Cu}$ and $\mathrm{Pb}$ at the flowering and grain maturity stages.

\section{Effect of sludge amendment on growth and productivity:}

The data of all parameters adopted for comparison (No. of flowers/spike, No. of seeds/spike, weight of 100 grain and yield) showed almost the same trend where the addition of more sludge (S) improved all studied characters compared to control natural soil.

As for quality (expressed as No. of seeds/spike), sludge was able to increase the number of seeds/spike from 40 (in control treatment) to 49.7 at sludge concentration of $10 \%(\mathrm{~S})$, to 54 at sludge concentration of $20 \%$ and 54.3 at sludge concentration of $30 \%(\mathrm{~S})$.

The data of Table (5) clearly indicated that the addition of sludge improved seed quality (expressed as weight of 100 seeds) from $5.7 \mathrm{gm}$ (in the control treatment) to $6.00 \mathrm{gm}$ at sludge (S) concentration of $10 \%$, to $6.30 \mathrm{gm}$ at sludge concentration of $20 \%$ (S) to 6.03 at sludge concentration of $30 \%$.

The same trend of improvement was also revealed by total yield (Ton/ Feddan) which showed regular increase in sludgeamended soils (S). The data showed that the best yield (1.69 Ton/ Feddan) was reported at the sludge concentration of $20 \%$.

\section{DISCUSSION}

\section{Sewage sludge as a fertilizer:}

Both of sewage sludge, as an organic fertilizer, and soil endomycorrhiza, as a biofertilizer, became very important elements in sustainable agriculture. Because of the low cost of the first element and the ability to increase the latter element in soil both have been adopted in many countries. 
Mansour, et al.

Table (3): Effect of different sludge concentrations on total protein at flowering and grain maturity stages.

\begin{tabular}{ccc}
\hline Growth Stage & Treatment & Total Protein (\%) \\
\hline Flowering & C & $7.867 \pm 0.120$ \\
(after 75 days) & S 10 \% & $8.433 \pm 0.233$ \\
& S 20 \% & $9.133 \pm 0.067$ \\
S 30 \% & $9.733 \pm 0.186$ \\
Grain maturity & LSD (5 \%) & $\mathbf{0 . 5 5 9}$ \\
(after 150 days) & C & $9.713 \pm 0.195$ \\
& S 10 \% 20 & $9.736 \pm 0.070$ \\
& S 30 \% & $9.860 \pm 0.070$ \\
& LSD (5 \%) & $10.531 \pm 0.286$ \\
\hline
\end{tabular}

Abbreviations: C; Control natural soil, S; Non- Mycorrhized soil treated with sludge, Values in the table are means \pm standard, LSD; least significant difference at $\mathrm{P}=0.05$.

Table (4): Effect of different sludge concentrations on heavy metals uptake at flowering and grain maturity stages.

\begin{tabular}{|c|c|c|c|c|c|c|}
\hline $\begin{array}{l}\text { Growth } \\
\text { Stage }\end{array}$ & Treatment & Zn (mg/gm) & Mn (mg/gm) & $\mathrm{Fe}(\mathrm{mg} / \mathrm{gm})$ & $\mathrm{Cu}$ (mg/gm) & $\mathrm{Pb}$ (mg/gm) \\
\hline \multirow{5}{*}{$\begin{array}{c}\text { Flowering } \\
\text { (after } 75 \\
\text { days) }\end{array}$} & $\mathbf{C}$ & $0.0217 \pm 0.0012$ & $0.0137 \pm 0.0015$ & $0.4147 \pm 0.0097$ & $0.0087 \pm 0.0007$ & $0.0237 \pm 0.0009$ \\
\hline & S $10 \%$ & $0.0320 \pm 0.0021$ & $0.0190 \pm 0.0006$ & $0.8983 \pm 0.0544$ & $0.0243 \pm 0.0007$ & $0.0553 \pm 0.0072$ \\
\hline & S $20 \%$ & $0.0367 \pm 0.0019$ & $0.0343 \pm 0.0029$ & $1.1460 \pm 0.0462$ & $0.0363 \pm 0.0071$ & $0.0677 \pm 0.0003$ \\
\hline & S $30 \%$ & $0.0553 \pm 0.0050$ & $0.0570 \pm 0.0120$ & $1.6887 \pm 0.1926$ & $0.0423 \pm 0.0030$ & $0.0887 \pm 0.0044$ \\
\hline & LSD (5\%) & 0.1682 & 0.1682 & 0.2343 & 0.0090 & 0.0113 \\
\hline \multirow{5}{*}{$\begin{array}{c}\text { Grain } \\
\text { maturity } \\
\text { (after } 150 \\
\text { days) }\end{array}$} & $\mathbf{C}$ & $0.0184 \pm 0.0021$ & $0.0061 \pm 0.0006$ & $0.4589 \pm 0.0093$ & $0.0046 \pm 0.0002$ & $0.0109 \pm 0.0001$ \\
\hline & S $10 \%$ & $0.0194 \pm 0.0014$ & $0.0062 \pm 0.0014$ & $0.7041 \pm 0.0462$ & $0.0066 \pm 0.0001$ & $0.0707 \pm 0.0035$ \\
\hline & S $20 \%$ & $0.0216 \pm 0.0004$ & $0.0120 \pm 0.0001$ & $0.7461 \pm 0.0106$ & $0.0109 \pm 0.0001$ & $0.1146 \pm 0.0061$ \\
\hline & S $30 \%$ & $0.0221 \pm 0.0007$ & $0.0145 \pm 0.0014$ & $0.9668 \pm 0.0015$ & $0.0110 \pm 0.0011$ & $0.1419 \pm 0.0002$ \\
\hline & $\begin{array}{c}\text { LSD (5 } \\
\%)\end{array}$ & 0.0047 & 0.0042 & 0.0561 & 0.0014 & 0.0075 \\
\hline
\end{tabular}

Abbreviations: C; Control natural soil, $\mathbf{S}$; Non- Mycorrhized soil treated with sludge, Values in the table are means \pm standard, LSD; least significant difference at $\mathrm{P}=0.05$. 
SINAI of Journal of Applied Sciences (ISSN: 2314-6079) Vol. :(2) Is.:(1), Apr. 2013

Table (5): Effect of different sludge concentrations on growth and productivity of wheat plant.

\begin{tabular}{cccccc}
\hline \multirow{2}{*}{ Treatment } & \multicolumn{5}{c}{ Growth \& Productivity } \\
\cline { 2 - 6 } & $\begin{array}{c}\text { No. of } \\
\text { flowers/spike }\end{array}$ & $\begin{array}{c}\text { No. of } \\
\text { grain/spike }\end{array}$ & $\begin{array}{c}\text { Wt. of } \\
\mathbf{1 0 0} \text { seeds (gm) }\end{array}$ & $\begin{array}{c}\text { Total Plant Yield } \\
\text { (gm) }\end{array}$ & $\begin{array}{c}\text { Total Yield } \\
\text { (Ton/Feddan) }\end{array}$ \\
\hline C & $86.00 \pm 2.00$ & $40.00 \pm 2.89$ & $5.75 \pm 0.08$ & $2.30 \pm 0.19$ & $1.16 \pm 0.12$ \\
S 10 \% & $96.00 \pm 3.46$ & $49.67 \pm 0.88$ & $5.97 \pm 0.09$ & $2.97 \pm 0.08$ & $1.48 \pm 0.04$ \\
S 20 \% & $109.67 \pm 2.19$ & $54.00 \pm 3.06$ & $6.28 \pm 0.06$ & $3.39 \pm 0.19$ & $1.69 \pm 0.09$ \\
S 30 \% & $110.00 \pm 8.72$ & $54.33 \pm 2.96$ & $6.03 \pm 0.14$ & $3.28 \pm 0.24$ & $1.64 \pm 0.12$ \\
LSD (5 \%) & 13.25 & 8.97 & 0.35 & 0.74 & 0.36 \\
\hline
\end{tabular}

Abbreviations: C; Control natural soil, S; Non- Mycorrhized soil treated with sludge, Values in the table are means \pm standard, LSD; least significant difference at $\mathrm{P}=0.05$.

Sewage sludge contains useful compounds of potential environmental value The organic matter content in sewage sludge can improve soil physical, chemical, and biological properties reflected in better cultivation and aquiferous capacity of soil (FAO, 1992 and Csattho, 1994). Furthermore, sludge applications have resulted in some other improvements of soil characters revealed by: elevated levels of P Silva et al. (2002), development the humic fraction of organic matter Meloet al. (1994), and increasing the cation exchange capacity (Oliveira et al., 2002).

Regarding the chemical analysis of sludge used in the present study, the results indicated clearly that the load of heavy metals especially $\mathrm{Cd}, \mathrm{Cu}, \mathrm{Fe}$, and $\mathrm{Pb}$ came within the permissible limits by comparison with the critical levels $(\mathrm{mg} / \mathrm{kg})$ reported in many countries like Japan (Nishimune, 1993), USA (US EPA, 1999), Denmark (Carrington 2001), Europe Union (European Commission, 2001), Estonia (Kahruet al., 2002), Pakistan (Usman et al., 2005), Botswana (Veronica et al., 2006), Germany (Dubey et al., 2006), China (Liu et al., 2007), Syria (Al-Zoubi et al., 2008), Tunisia (Cherifet al., 2009).
2. Effect of sludge amendment on wheat growth and productivity:

\section{A. Fresh and dry weight:}

The data revealed that sludge amendment significantly increased fresh and dry weight compared with control. The increase in biomass (fresh \& dry weight) upon amending sewage sludge was also noticed by several investigators in different countries like Sharif et al. (2009) in Pakistan; Bozkurt \& Yarılgaç (2003) in Turkey; Mohammad \& Athamneh, (2004) in Jordan; Lakhdaret al. (2010) in Tunisia; Kotb (1999); Mazenet al. (2010); Galal (2012) in Egypt.

The concentration of $20 \%$, which have been reported as a most suitable rate for wheat fertilization, in our study, was also noticed for wheat in Turkey by Özyazici (2013) during his study on the yield and yield-components of wheat in a croprotation program and in India by Bose $\boldsymbol{\&}$ Bhattacharyya (2012).

\section{B. Heavy metals uptake:}

Data of the present study clearly showed that the five heavy metals under test did not follow the same pattern of uptake, while $\mathrm{Fe}, \mathrm{Cu}$ and $\mathrm{Pb}$ followed a 
Mansour, et al.

specific pattern $\mathrm{Zn}$ and $\mathrm{Mn}$ followed another pattern.

Plants absorbed greater amounts of $\mathrm{Fe}, \mathrm{Cu}$ and $\mathrm{Pb}$ upon increasing sludge concentration in both mycorrhized and sludge-amended soils.

However, by comparison, the absorption rate in sludge-amended soils is much greater than that in mycorrhized soil, indicating AM fungi can help alleviate metal toxicity to plants by reducing metals translocation from root to shoot (Hinsley et al., 1982; Jarausch-Wehrheim et al., 1999; Mc-Grath et al., 2000).

In Egypt, a survey of literature up to the present time on studies related to the effect of sewage sludge applications on the uptake of heavy metals in wheat or other crops referred toward a clear selectivity of absorption among plant tissues.

The study on wheat by Galal (2012) is by far the most relevant one. He found that sludge application combined with biofertilizer such as AM, Azospirillum and Rhizobium greatly improve the yield.

While, in other crops Badawy \& ElMotaium (2000) noticed that the concentrations of $\mathrm{Cu}, \mathrm{Zn}, \mathrm{Cd}$, and $\mathrm{Pb}$ in tomato leaves and fruits were increased upon the increase in sewage sludge.

Very similarly observations were also reported by Rabie (2005) during his study on red-kidney and by Mazenet al. (2010) during their study on wheat grown in a desert reclaimed soil. In both studies, the accumulation of heavy metals was much more in roots than shoots.

\section{Total yield and yield quality:}

The effect of sludge amendment and soil mycorrhization, separately or in combination, was studied and also various concentrations of sludge were tested.
The data, clearly showed a prominent positive effect of both treatments (separately or combined) on both total yield and yield quality.

Our observation on the improvement of total yield and yield quality as a result of sludge amendment were also noticed by many investigators worldwide like Chatha et al. (2002); Jamil et al. (2004); Akrivos et al. (2006); Tamrabet et al. (2009); Aslam et al. (2011); Özyazıcı (2013) who noticed a significant effect on yield and yield quality upon the amendment of sludge.

\section{REFERENCES}

Akrivos, J.; Kavvadias, V.; Paschalldis, C.; Rigas, F.; Zakinthinos, G.; Papadopoulos, P.; Dimirkou, A.; Rouskas, D.; De Kreij, C. (2006). Effect of Sewage Sludge Applied on Wheat and Soil fertility. Journal or Balkan Feolngy.vol. 9. No 2.

Alcantara, S.; Pérez, D. V.; Almeida, R. A.; Silva, G. M.; Polidoro, J.C.; Bettiol, W. (2009). Chemical changes and heavy metal partitioning in an oxisol cultivated with maize (Zea mays L.) after 5 years disposal of a domestic and an Industrial sewage sludge. Water, Air, and Soil Pollution 203: 3-16.

Al-Zoubi, M. M.; Arslan, A.; Abdelgawad, G.; Pejon, N.; Tabbaa, M.; Jouzdan, O. (2008). The effect of sewage sludge on productivity of a crop rotation of wheat, maize and vetch) and heavy metals accumulation in soil and plant in Aleppo governorate. AmericanEurasian J. Agric. \& Environ. Sci., 3 (4): 618-625.

Angın, I. and Yağanoğlu, A.V. (2009). Application of sewage sludge as a soil physical and chemical amendment. Ekoloji 19 (73): 39-47. 
Angın, I. and Yağanoğlu, A.V. (2011). Effects of sewage sludge application on some physical and chemical properties of a soil affected by wind erosion. Journal of Agricultural Science Technology 13: 757-768.

Aslam, M.; Khan, M.A.; Awan, I.U.; Khan, E.A.; Khan, A.A.; Jilani, G. (2011). Effect of Single and Combined Use of Various Organic Amendments on Wheat Grown over Green Manured Soil: I. Growth and Yield Attributes. Pakistan Journal of Nutrition 10 (7): 640-646.

Badawy, S.H. and El-Motaium, R.A (2000). Fate of some heavy metals in sandy soil amended with sewage sludge and their accumulation in plants. ICEHM2000, Cairo University, Egypt, September, page 483- 494.

Bose, S. and Bhattacharyya, A.K. (2012). Effect of Industrial Sludge Application on Soil Nitrogen and Wheat Plant Response. Open Journal of Soil Science, 2:133-145. (http://www.SciRP.org/journal/ojss).

Bozkurt, M.A. and Yarilgaç, T. (2003). The effects of sewage sludge applications on the yield, growth, nutrition and heavy metal accumulation in apple trees growing in dry conditions. Turkish Journal of Agriculture and Forestry 27: 285292.

Bozkurt, M.A.; Akdeniz, H.; Keskin, B.Y.; Ibrahim, H. (2006). Possibilities of using sewage sludge as nitrogen fertilizer for maize. Acta Agriculture Scandinavica, Section B Soil \& Plant Science 56: 143-149.

Breiman, A. and Graur, D. (1995). Wheat Evaluation." Israel J Plant Sci. 43:58-95.
Carrington, E.G. (2001) Evaluation of sludge treatments for pathogen Reduction - final report Study Contract No B4-3040/2001/322179/ MAR/A2 for the European Commission Directorate-General Environment. WRc Ref: CO 5026/1/ 12787.

Chatha, T.H.; Haya, R.; Latif, I. (2002). Influence of sewage sludge and organic manures application on wheat yield and heavy metal availability. Asian Journal of Plant Sciences 1: 79-81.

Cherif, H.; Ayari, F.; Ouzari, H.; Marzorati, M.; Brusetti, L.; Jedidi, N.; Hassen, A.; Daffonchio, D. (2009). Effects of municipal solid waste compost, farmyard manure and chemical fertilizers on wheat growth, soil composition and soil bacterial characteristics under Tunisian arid climate. European journal of soil biology (45) 138- 145.

Csattho, P.(1994). The Heavy Metal Pollution of the Environmental and the Agricultural Production, Temati kussza kirodalmi Szemle, AkaprintKiado, Budapest, pp. 18-27

.Du, W.; Jiang, J.; Gong, C. (2012). Primary research on agricultural effect of Sludge - impact of sludge application on crop seeds germination and seedling growth. Procedia Environmental Sciences 16: 340-345.

Dubey S. K.; Yadav, R. K.; Chatuvedi, P. K.; Goyel, B., Yadav R.; Minhas, P.S. (2006). Agricultural Uses of Sewage Sludge and Water and Their Impact on Soil Water and Environmental Health in Haryana, India, Abstract of $18^{\text {th }}$ World Congress of Soil Science, Philadelphia, 9-15. 
Mansour, et al.

Epstein, E. (2003). Land application of Sewage Sludge and Biosolids.Lewis PublishersCRC Press Company, New York, USA.

European Commission (2001). Disposal and Recycling Routes of Sewage Sludge Part 3," Scientific and Technical Re- port, European Commission DG Environment.

FAO (1992). Agricultural Use of Sewage, Waste Water Treat- ment and Use in Agriculture, FAO Irrigation and Drawing Paper 47, Food and Agriculture Organization of the United Nations, Rome.

Galal, Y.G.M. (2012). Recycling of Treated Sewage Sludge in Sustainable Agriculture. Arab Journal of Nuclear Sciences and Applications, 45(2): 548-560.

Gu, C.; Bai, B.; Tao, T.; Chen, G.; Shan, Y. (2013). Effect of sewage sludge amendment on heavy metal uptake and yield of ryegrass seedling in a Mudflat soil. Journal of Environmental Quality 42: 421-428.

Hinsley, T.D.; Redborg, K. E.; Zielger, E. L.; Alexander, J. D. (1982). Effect of soil cation exchange capacity on uptake of the cadmium by Corn. Soil Sci. Soc. Am. J. 46: 490497.

Jamil, M.; Qasim, M.; Umar, M.; Rehman, K. (2004) Impact of Organic Wastes (Sewage Sludge) on the Yield of Wheat (Triticumaestivum L.) in a Calcareous Soil. Int. J. Agri. Biol., 6 (3): 465-467.

Jarausch-Wehrheim, B.; Mocquot，B.; Mench, M. (1999). Absorption and translocation of sludge-borne zinc in field-grown maize (Zea mays L.). European Journal Agronomy 11: 2333.
Kahru, A.; Põllumaa, L.; Ivask, A.; Kasemets, K.; Virta, M.; Francois, M.; Dubourguier, H.C.; Douay, F. (2002). Biotests and Biosensors in the Analysis of (eco) toxicological Risk of Soils Highly Polluted by Cadmium, Lead and Zinc: Bioavailable Fractions cause Toxic Hazard.

Kalembasa, S.; Baran, S.; Drozd, J. (2004). Humus forming value of wastes as a factor affecting soil environment. Rocz.Glebozn., LV, (1): 25, [in Polish]

Kidd, P.S.; Domínguez- Rodríguez, M.J.; Díez, J.; Monterroso, C. (2007). Bioavailability and plant accumulation of heavy metals and phosphorus in agricultural soils amended by long-term application of sewage sludge. Chemosphere 66: 1458-1467.

Kotb, EA. (1999). Plant response to biofertilization in soil amended with irradiated sewage sludge. M.Sc. Faculty of Science, Ain Shams University, Cairo, pp. 129.

Lakhdar, A.; Iannelli, M.A.; Debez, A.; Massacci, A.; Jedidib, N.; Abdellya, C. (2010) .Effect of municipal solid waste compost and sewage sludge use on wheat (Triticum durum): growth, heavy metal accumulation, and antioxidant activity. J Sc. Food Agri. 2010; 90: 965-971.

Little, T.M. and Hills, F.J. (1978). Agricultural Experimentation Design and Analysis. Wiley, New York, USA.

Liu, X.C.; Yang, M.; Zhang, Y.; Yang, X.P.; Gan Y.P. (2007). Microbial community comparison of different biological processes for treating the same sewage. World J. MicrobiolBiotechnol. 23: 135-143. 
Mazen, A.; Faheed, F.A.; Ahmed, A.F. (2010). Study of potential impacts of using sewage sludge in the amendment of desert reclaimed soil on wheat and jews mallow plants. Braz. Arch. Biol. Technol. 53 (4): pp. 917-930.

Mc-Grath, S. P.; Zhao, F.J.; Dunham, S.J.; Crosland, A.R.; Coleman, K. (2000). Long-term changes in extractability and bioavailability of zinc and cadmium after sludge application. J. Environ. Qual. 29: 875-883.

Melo, W. J.; Marques, M. O.; Santiago, G.; Chelli, R.A (1994). Efeito de doses crescentes de lodo de esgotosobrefrações da materialorgânica e CTC de um Latossolocultivado com cana-de-açúcar. R. Bras. Ci. Solo, 18: 449- 455.

Mohammad, M. J. and Athamneh, B.M. (2004). Changes in Soil Fertility and Plant Uptake of Nutrients and Heavy Metals in Response to Sewage Sludge Application to Calcareous Soils. Journal of Agronomy 3 (3): 229-236.

Mosquera-Losada, M-R.; MunozFerreiro, N.; Rigueriro-Podriguez, A. (2010). Agronomic characterization of different types of sewage sludge: Policy implication. Waste Management, 30 (3): 429.

Nishimune, A. (1993). Combinations of Organic and Inorganic Fertilizers for Crop Production," Extension Bulletin. 372: 1-25.

Oliveira, F. C.; Mattiazzo, M.E.; Marciano, C.R.; Rosseto, R. (2002). Efeitos de aplicaçõessucessivas de lodo de esgotoem Latossolo Amarelodistróficocultivado com cana-de-açúcar: Carbonoorgânico, condutividadeelétrica, $\mathrm{pH}$ e CTC. R. Bras. Ci. Solo, 26: 505-519
.Özyazıcı, M. A. (2013). Effects of sewage sludge on the yield of plants in the rotation system of wheat-white head cabbage-tomato. Eurasian Journal of Soil Science 2: 35 - 44.

Petersen S. O.; Petersen J.; Rubak, G.H. (2003). Dynamics and plant uptake of nitrogen and phosphorus in soil amended with sewage sludge. Applied Soil Ecology (24): 187-195.

Rabie, G. H. (2005) .Contribution of arbuscularmycorrhizal fungus to red kidney and wheat plants tolerance grown in heavy metal-polluted soil. African Journal of Biotechnology 4 (4): pp. 332-345.

Rangaraj, T.; Somasundaram, E.; Mohamed, A.M.; Thirumurugan, V.; Ramesh, S.; Ravi, S. (2007). Effect of Agro industrial wastes on soil properties and yield of irrigated finger millet (Eleusinecoracana L. Gaertn) in coastal soil. Res. J. Agric. Biol. Sci., 3(3): 153-156.

Royse, D. J. and Ries, S. M. (1978). The influence of fungi isolated from peach twigs on the pathogenicity of Cytosporacinta.Phytopathology68: 603-607.

Samaras, V.; Tsadilas, C. D.; Stamatiadis, S. (2008). Effects of repeated application of municipal sewage sludge on soil fertility, Cotton Yield, and Nitrate Leaching. Agronomy Journal100 (3): 477-483.

Sharif, M.; Sarir, M.S.; Bakht, J.; Saud, S.; Ali, A.; Ahmad, M. (2009). Response of wheat to the inoculation of arbuscularmycorrhizal fungi in salt affected soil. Sarhad J. Agric. Vol.25, No.2.

Silva, J. E.; Resck, D. V. S.; Sharma, R.D. (2002). Alternativaagronômica para o biossólidoproduzido no Distrito Federal. I - Efeitonaprodução de milho e adição de metaispesadosem Latossolo no 
cerrado. R. Bras. Ci. Solo, 26: 487495.

Snedecor, G.W. and Cochran, W.G. (1980). Statistical Methods. $7^{\text {th }}$ Ed., The Low State Univ. Press, Ames, Lowa, USA.

Standard methods for examination of water and wastewater, $\mathbf{2 0}^{\text {th }}$ edition (1999). American Public Health Association/ American Water Works Association/ Water Environment Federation, Washington DC, USA.

Tamrabet, L.; Bouzerzour, H.; Kribaa, M.; Makhlouf, M. (2009). The effect of sewage sludge application on durum wheat (Triticum durum). Int. J. Agric. Biol., 11: 741-745.

Togay, N.; Togay, Y.; Doğan, Y. (2008). Effects of municipal sewage sludge doses on the yield, some yield components and heavy metal concentration of dry bean (Phaseolus vulgaris L.). African Journal of Biotechnology 7(17): 3026-3030.

TRADE/WP.8/AC.1/SEM.7/2002/4/S.48 (Original English). US EPA, (1999).
Environmental regulations and technology. Control of pathogens and vector attraction in sewage sludge. Report EPA/625/R-92/013, US EPA, Washington DC.

Usman, A.R.A.; Kuzyakov, Y.; Stahr, K. (2005). Effect of Immobilizing Substances and Salinity on Heavy Metals Availability to Wheat Grownon Sewage SludgeContaminated Soil. Soil \& Sediment Contamination, 14:329-344.

Veronica, N.; Otlogetswe, T.; Sisai, M. (2006). The effect of ageing on the fertilizer value of sludge from Botswana. J. Appl. Sci. Environ. Mgt. 10 (3): 109 - 115.

Yan, S.; Bala Subramanian, S.;Tyagi, R.D.; Surampalli, R.Y. (2009). Wastewater sludge characteristics. In Sustainable Sludge Management: Production of Value Added Products. American Society of Civil Engineers, Reston, Virginia, USA. Pp 6-36. 
SINAI of Journal of Applied Sciences (ISSN: 2314-6079) Vol. :(2) Is.:(1), Apr. 2013

الملخص العربي

تأثير التسميل بحمأة الصرف الصحي المعالجة علي نمو وإنتاجية القمح

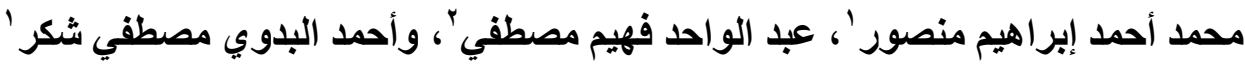

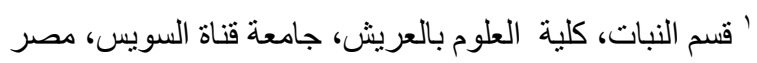

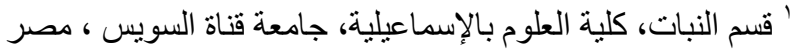

يعتبر نبات القمح من أهم محاصيل الحبوب الإستر اتيجية في مصر و العديد من بلدان العالم إلا أن الإنتاج السنوي في

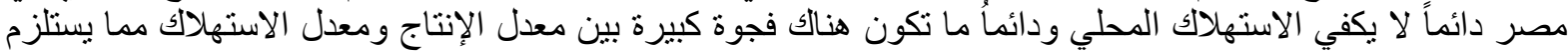

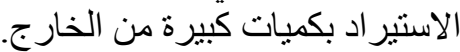

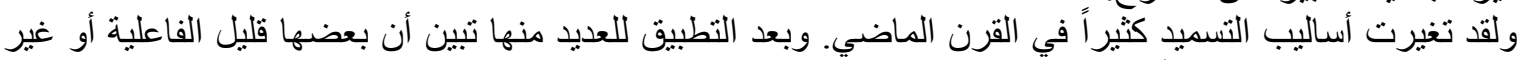

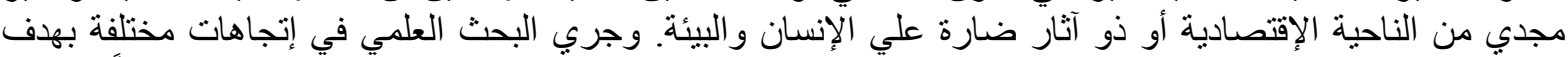

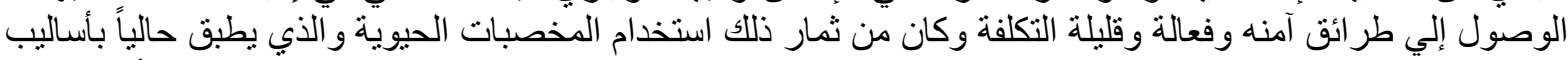

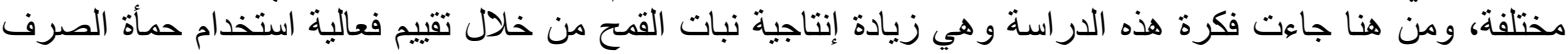
الصحي (كمخصب عضوي). وقد تم استخدام حمأة ألصرف الصحي المجففة (composted) في الهواء كسماد وتم الحصول عليها من من محطة

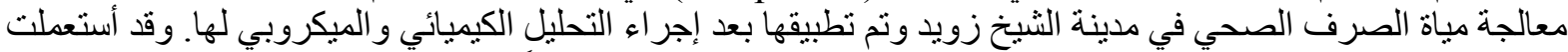

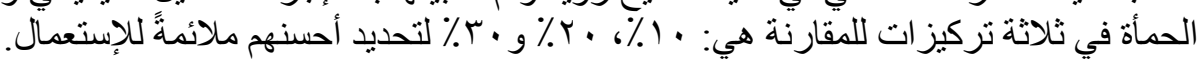

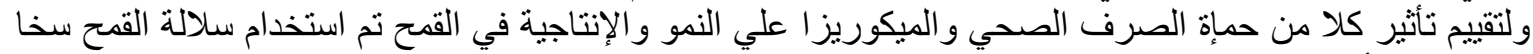

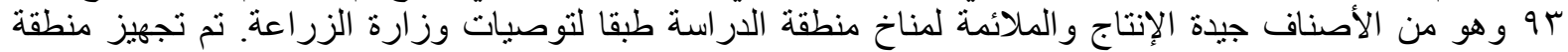

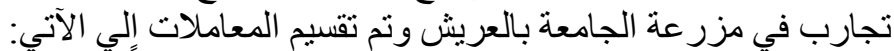

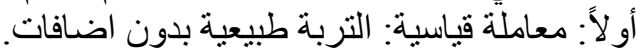

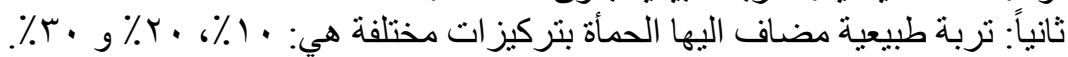

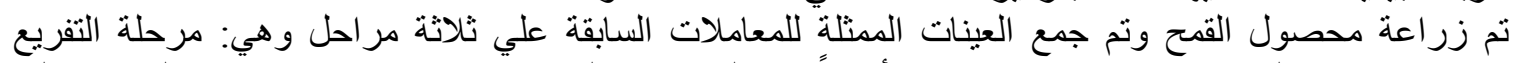

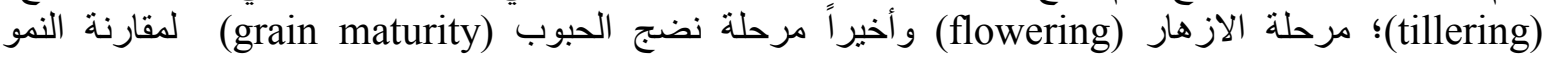

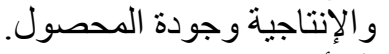

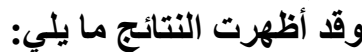

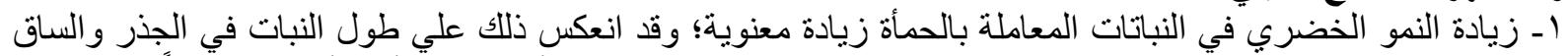
وكذلك الوزن الطازج والجاف للنبات وكان ذلك عن طريق زيادة كمية الحمأة وكان التثأثير أكثر وضوحاً في مرحلة

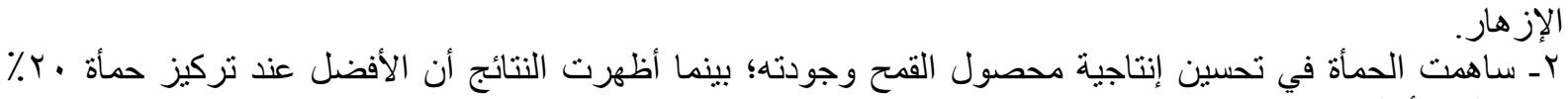

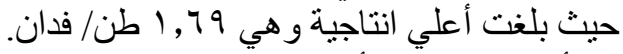

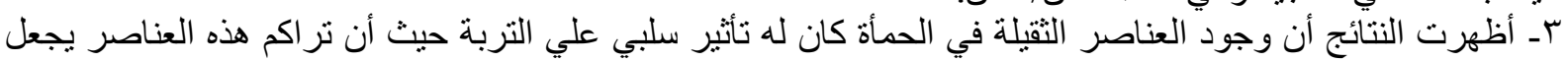

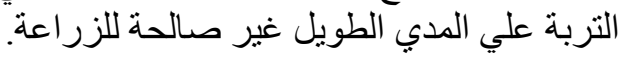

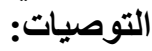
اـ لتحسين الإنتاجية في التربة الصحر اوية من المكن تطبيق استراتيجية زيادة التربة بالحمأة لما تحتوية من عناصر مفيدة لخصوبة التربة.

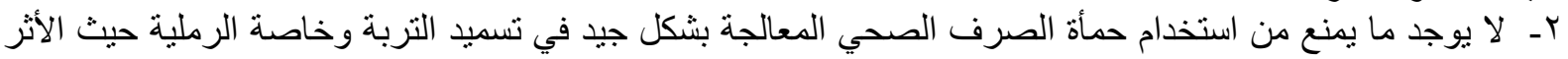

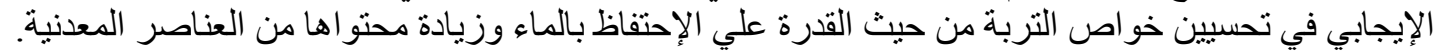

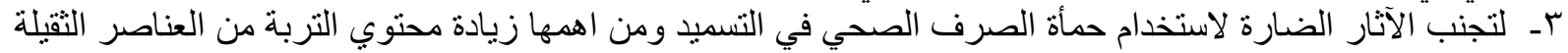

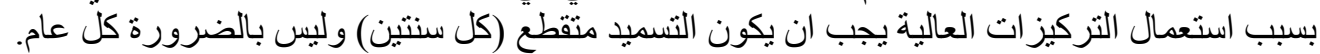

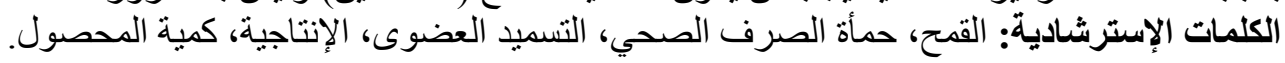

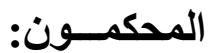

أستاذ الفسيولوجي المساعد، كلية العلوم، جامعة بورسعيد، مصر. أستاذ المحاصيل المساعد، كلية العلوم الزراع، جاعية البيئية بالعريش، جامعة فيشة قناة السويس، مصر.

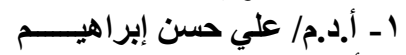

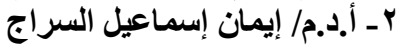


Mansour, et al. 